\title{
A prospective randomized trial comparing patent blue and methylene blue for the detection of the sentinel lymph node in breast cancer patients
} \author{
Tatiane Coelho Capel de Resende ${ }^{5}$

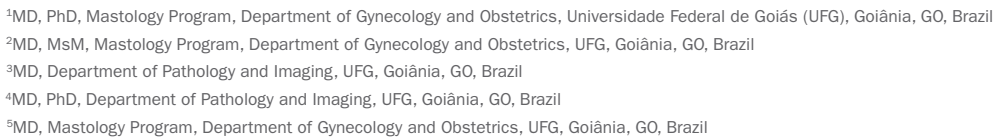

Régis Resende Paulinelli1*, Ruffo Freitas-Junior ${ }^{1}$, Rosemar Macedo de Souza Rahal ${ }^{1}$, luis Fernando de Pádua Oliveira ${ }^{2}$, Maria Helena Tavares Vilela ${ }^{3}$, Marise Amaral Rebouças Moreira ${ }^{4}$, Katyane larissa Alves ${ }^{5}$, Marina Berquó Peleja ${ }^{5}$,

Study conducted at Universidade Federa de Goiás (UFG), Goiânia, GO, Brazil

Article received: 5/16/2016 Accepted for publication: $5 / 31 / 2016$

*Correspondence: Address: Alameda Americano do Brasil, 282, Ed. City Hall, apto. 801 Goiânia, GO - Brazil Postal code: $74180-010$ rrpaulinelli@gmail.com

Funding: Partially funded by the Goiás State Foundation for the Support of Research (FAPEG), grant 01/2007

http://dx.doi.org/10.1590/1806-9282.63.02.118

\section{SUMmaRY}

Introduction: Methylene blue is more widely available and less expensive than patent blue, with an apparently lower risk of anaphylaxis.

Objective: The two dyes were compared regarding detection of the sentinel lymph node (SLN).

Method: A prospective, randomized trial involved 142 patients with invasive breast carcinoma. Sixty-nine (49.3\%) assigned to patent blue (group A) and 71 (50.70\%) to methylene blue (group B). Thirty-five patients (25.0\%) were clinical stage III or IV; 55 (38.7\%) had axillary lymph nodes affected; and 69 (49.3\%) underwent neoadjuvant chemotherapy. Two patients were excluded because the dye type was not recorded.

Results: Patients and tumor characteristics were similar in both groups. SLNs were identified in 47 women $(68.1 \%)$ in group A and $43(60.6 \%)$ in group B $(\mathrm{p}=0.35)$. SLNs were affected in 22 cases $(51.2 \%)$ in group A and $21(48.8 \%)$ in group B ( $\mathrm{p}=0.62)$. The SLN was the only node affected in 12 cases $(54.5 \%)$ in group A and six $(33.3 \%)$ in group $B(p=0.18)$. The time and degree of difficulty involved in identifying the SLN were similar in both groups. There were no complications or allergies.

Conclusion: Methylene blue performed as well as patent blue in identifying the SLN in breast cancer patients.

Keywords: breast cancer, sentinel lymph node, patent blue, methylene blue, randomized controlled trial.

\section{INTRODUCTION}

Prior to the first studies on sentinel lymph nodes, axillary lymph node dissection was considered the standard treatment for patients with early stage breast cancer. ${ }^{1,2}$ Indeed, the extent of axillary involvement is one of the most important independent prognostic factors for tumor recurrence and patient survival. ${ }^{2,3}$ Nevertheless, dissection of the entire axillary lymph node chain results in greater morbidity, and a considerable percentage of the patients previously submitted to this procedure were later found to have no axillary metastasis, with the intervention therefore having been unnecessary. ${ }^{1}$

The introduction of the sentinel lymph node biopsy was one of the greatest advances in the surgical treatment of breast cancer and has proved an excellent predictor of axillary involvement in initial tumors. ${ }^{4,5}$ Since sentinel lymph node biopsy involves fewer risks and less morbidity, it has gained followers worldwide and is currently the standard treatment for axillary management in breast cancer patients. ${ }^{6}$ This method enables axillary involvement to be diagnosed with 
good sensitivity. Therefore, complete dissection of the axillary lymph nodes became restricted to those cases in which metastases are detected in the sentinel lymph node.

When only micro-metastases are found in the sentinel lymph node, complete dissection is considered unnecessary. In the case of conservative surgery with conventional radiotherapy, standard axillary dissection can be avoided when only one or two lymph nodes are affected. ${ }^{8}$ In the case of mastectomy or when up to three lymph nodes are affected, axillary radiotherapy can be performed, with lower morbidity rates compared to axillary dissection. ${ }^{9,10}$

Some investigators have preferred the use of nuclear medicine techniques to identify the sentinel lymph node due to the greater simplicity of those techniques compared to the use of dyes. ${ }^{5,11}$ With dyes, the surgeon may require slightly more training and the learning curve may be steeper..$^{12}$ After the initial training period, however, the sentinel lymph node identification rate with dyes tends to be similar to that obtained with nuclear medicine techniques, reaching $98 \%$ in some more recent reports. ${ }^{13}$ Furthermore, once the sentinel lymph node is identified, accuracy is the same irrespective of the method used and the lymph node detection rate.

The principal problems involved in radioactive tracer techniques are their technological complexity and high costs. ${ }^{5}$ In this respect, the use of dyes is still the most economically viable alternative, principally in public healthcare services with few resources, a common scenario in developing countries. The cost of the same procedure may be much lower with the use of dyes compared to the use of radioactive tracers.

Different vital dyes have been used to identify the sentinel lymph node: patent blue, isosulfan blue and, less commonly, methylene blue. ${ }^{11,13}$ Although methylene blue is more readily available and considerably less expensive than the others, some authors claim that it diffuses more rapidly in peripheral tissues, staining a larger portion of the breast with the blue dye and, to a certain extent, hampering the procedure. ${ }^{14-16}$ Other authors have reported similar accuracy and sentinel lymph node detection rates with methylene blue and with patent blue. ${ }^{13,17}$ There appears to be a lower risk of anaphylaxis with methylene blue compared to the other dyes. ${ }^{18}$ Therefore, the objective of the present study was to compare the detection rate and accuracy of two different dyes, methylene blue and patent blue, for the identification of the sentinel lymph node in patients with breast cancer.

\section{Method}

In this prospective randomized study, 142 patients with a diagnosis of invasive breast carcinoma were included.
The patients were receiving care within the Breast Program at the University of Goiás Teaching Hospital. The institutional review board approved the study. All the patients signed an informed consent form.

The participants were scheduled to undergo sentinel lymph node biopsy or complete axillary lymph node dissection. The women were enrolled irrespective of their clinical staging, comorbidities or previous treatment (previous surgeries, chemotherapy or radiotherapy). A total of 69 patients $(49.3 \%$ ) received a $2-\mathrm{mL}$ injection of patent blue (Group A) and $71(50.7 \%)$ a $2-\mathrm{mL}$ injection of $1 \%$ methylene blue (Group B). Two patients were excluded from the analysis because the type of dye used had not been recorded appropriately.

For the calculation of sample size, the factors taken into consideration were the possibility of a sentinel lymph node detection rate of $95 \%$ with patent blue ${ }^{11,19}$ and a hypothetical difference of $20 \%$ less in the detection rate with the use of methylene blue. In fact, the few published studies available comparing the two methods failed to show any difference between them. ${ }^{15,20}$ Considering a confidence level of $5 \%$ and a power of the test of $80 \%$, a total of 116 patients would be required, divided into the two groups. To compensate for any possible losses, 142 patients were enrolled to the study.

The patients admitted to the study underwent various different steps that consisted of a detailed bilateral breast examination, laboratory tests including full blood count, alkaline phosphatase, aspartate aminotransferase (AST) and alanine transaminase (ALT), chest X-ray (posterior-anterior and lateral), ultrasonography of the upper abdomen, bone scintigraphy, bilateral mammography and the preoperative examinations appropriate for each individual case.

Mastectomy or quadrantectomy was performed in accordance at the discretion of the attending physician, together with sentinel lymph node biopsy. Level I, II and sometimes level III axillary lymphadenectomy was performed when axillary involvement was found immediately prior to surgery, either clinically, by palpation or from imaging tests. The patients were previously randomized using a computer-generated randomization system to the use of patent blue or methylene blue dye. According to the randomization group, $2 \mathrm{~mL}$ of $2.5 \%$ sterile patent blue dye or $2 \mathrm{~mL}$ of sterile methylene blue dye were injected into the peritumoral or periareolar region. Next, the site was massaged for 5 minutes. Sentinel lymph nodes were defined as all the lymph nodes stained blue or when the afferent lymphatic vessels were blue (Figure 1). Clinically suspect lymph nodes were not considered sentinel lymph nodes. 


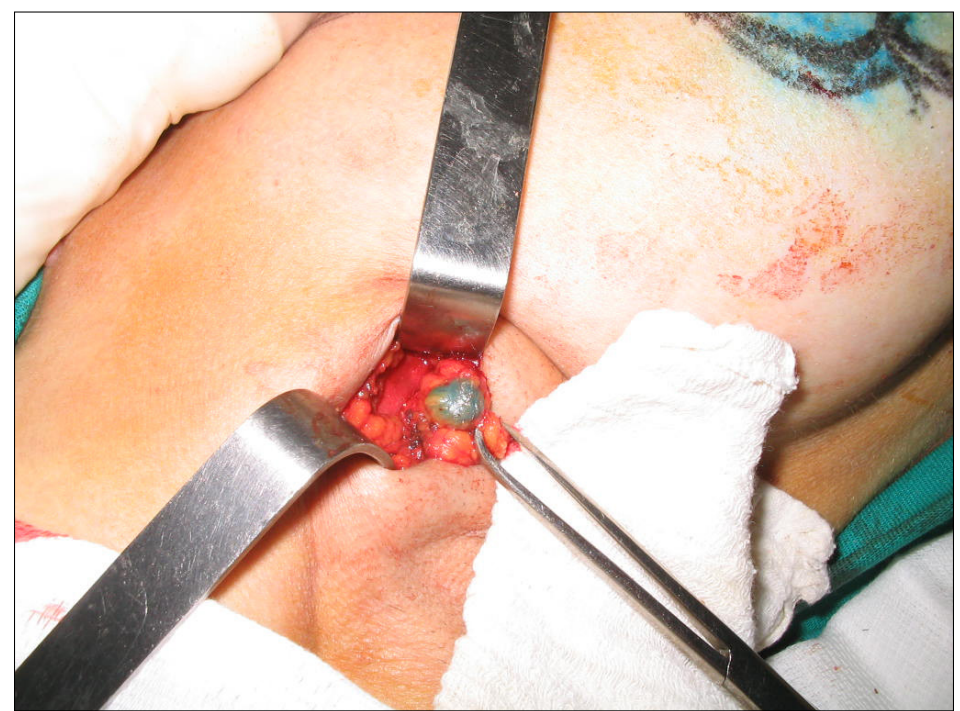

FIGURE 1 Sentinel node in the armpit identified by means of the color, after the periareolar injection of the blue dye.

The surgical specimen was sent to pathology and histological confirmation was reached by frozen section biopsy. The sentinel lymph nodes were submitted to histological evaluation separate from the rest of the lesion and from the other lymph nodes.

The data were collected on a form specifically designed for this study and entered into a database. SPSS statistical software package, version 15.0, was used for the statistical analysis. Chi-square test was used to compare accuracy between the two groups using the formulae for the comparison of two independent samples described by Galen \& Gambino. ${ }^{21}$ P-values $<0.05$ were considered statistically significant.

\section{RESULTS}

There were no statistically significant differences between the two groups with respect to the characteristics of the patients or their tumors (Table 1). The type of treatment given and the immediate results were similar in both groups (Table 2). The time required to identify the sentinel lymph node and the degree of difficulty encountered were similar in the two groups. The sentinel lymph node identification rate was similar in both groups, as were the other parameters compared (Table 3).

\section{Discussion}

The use of radioactive isotope techniques to identify the sentinel lymph node in patients with breast cancer has been limited, mainly because a considerable proportion of healthcare services cannot afford their costs. Dyes are widely used with acceptable results, both in association with a radioactive isotope or on their own. ${ }^{22}$ However, the sentinel lymph node identification rate with dyes is largely dependent on the experience of the medical team. Giuliano et al. reported an increase in the sentinel lymph node identification rate with patent blue dye from 66 to 94\% as their experience increased. ${ }^{11,19}$

Although patent blue and isosulfan blue are the dyes most commonly used in the sentinel lymph node technique, some groups have reported success with the use of methylene blue. ${ }^{17,18}$ The difference in cost between the dyes is considerable and methylene blue is much more readily available in different hospitals. The cost of methylene blue may represent as little as $3 \%$ of the cost of patent blue or isosulfan blue. ${ }^{23}$ For healthcare institutions in developing countries, particularly those that depend on public funding, this cost reduction may make the use of the sentinel node technique more easily available.

The risk of allergic reactions ranges from 1 to $2 \%$ with patent blue and isosulfan blue, with these reactions being severe in some cases. ${ }^{17,18}$ Up to the present moment, there have been no reports of allergies with methylene blue. As the popularity of the sentinel lymph node technique increases, preference for the use of methylene blue rather than the other dyes may avoid many undesirable and potentially fatal allergic reactions. ${ }^{13}$ Furthermore, compared to the other dyes, methylene blue interferes less with oximetry. ${ }^{24}$ Nevertheless, a case has been reported in the literature of a pulmonary edema possibly related to the use of methylene blue for the detection of the sentinel lymph node. ${ }^{25}$ Another advantage of methylene blue is the possibility of being able to use it during pregnancy, which is not the case with the other dyes. ${ }^{26}$ 
TABLE 1 Characteristics of the patients and tumors.

\begin{tabular}{|c|c|c|c|}
\hline & Patent blue & Methylene blue & p-value \\
\hline Age (years) ${ }^{a}$ & $51.00(+11.48)$ & $52.82(13.44)$ & 0.39 \\
\hline Size of the tumor $(\mathrm{mm})^{\mathrm{b}}$ & $35.00(25.00-50.00)$ & $33.00(25.00-50.00)$ & 0.78 \\
\hline Clinical staging ${ }^{c}$ & & & 0.34 \\
\hline I & $8(11.6 \%)$ & $11(15.5 \%)$ & \\
\hline Ila & $28(40.6 \%)$ & $30(42.3 \%)$ & \\
\hline IIb & $14(20.3 \%)$ & $14(19.7 \%)$ & \\
\hline III & $17(24.6 \%)$ & 15 (21.1\%) & \\
\hline IV & $2(2.9 \%)$ & $1(1.4 \%)$ & \\
\hline Clinical involvement of axillae & $32(46.4 \%)$ & $22(31.0 \%)$ & 0.06 \\
\hline Histological grade ${ }^{c}$ & & & 0.90 \\
\hline I & $13(23.6 \%)$ & $16(28.6 \%)$ & \\
\hline II & $32(58.2 \%)$ & $28(50.0 \%)$ & \\
\hline III & $10(18.2 \%)$ & $11(19.6 \%)$ & \\
\hline Skin color ${ }^{d}$ & & & 0.73 \\
\hline White & $27(39.1 \%)$ & $32(45.7 \%)$ & \\
\hline Black & $7(10.1 \%)$ & $6(8.6 \%)$ & \\
\hline Brown & $35(50.7 \%)$ & $32(45.7 \%)$ & \\
\hline Histological type ${ }^{d}$ & & & 0.56 \\
\hline Invasive ductal carcinoma & $61(88.4 \%)$ & $60(84.5 \%)$ & \\
\hline Invasive lobular carcinoma & $3(4.3 \%)$ & $3(4.2 \%)$ & \\
\hline Others & $5(7.3 \%)$ & $8(11.3 \%)$ & \\
\hline Multicentric tumor ${ }^{d}$ & $13(18.8 \%)$ & $15(21.4 \%)$ & 0.70 \\
\hline
\end{tabular}

Mean ( \pm standard deviation), Student's t-test.

${ }^{b}$ Median (interquartile range), Mann-Whitney $U$ test.

in (\%), Mann-Whitney $\mathrm{U}$ test.

$\mathrm{d}_{\mathrm{n}}(\%)$, Chi-square test, with or without Yates' correction, or Fisher's exact test.

TABLE 2 Characteristics of the techniques and of the treatment.

\begin{tabular}{llll} 
& Patent blue & Methylene blue & p-value \\
\hline Lymph node dissection $^{\mathrm{a}}$ & $15.2( \pm 6.8)$ & $15.9( \pm 8.5)$ & 0.67 \\
\hline Lymph nodes affected $^{\mathrm{b}}$ & $1.0(0.0-2.5)$ & $0.0(0.0-5.0)$ & 0.93 \\
\hline Previous open biopsy $^{\mathrm{c}}$ & $15(21.7 \%)$ & $21(29.6 \%)$ & 0.29 \\
\hline Neoadjuvant chemotherapy $^{\mathrm{c}}$ & $39(56.5 \%)$ & $47(66.2 \%)$ & 0.24 \\
\hline Conservative surgery $^{c}$ & $37(53.6 \%)$ & $35(49.3 \%)$ & 0.87 \\
\hline
\end{tabular}

aMean ( \pm standard deviation), Student's t-test.

'Median (interquartile range), Mann-Whitney $\mathrm{U}$ test.

${ }^{c}$ (\%); Chi-square test.

TABLE 3 Results of sentinel lymph node investigation.

\begin{tabular}{llll} 
& Patent blue & Methylene blue & P-value \\
\hline Detection of sentinel lymph node & $47(68.1 \%)$ & $43(60.6 \%)$ & $0.35^{\text {a }}$ \\
\hline Involvement of sentinel lymph node & $22(51.2 \%)$ & $21(48.8 \%)$ & 0.62 \\
\hline Sentinel lymph node was the only node affected & $12(54.5 \%)$ & $6(33.3 \%)$ & $0.19^{\mathrm{a}}$ \\
\hline Number of sentinel lymph nodes & $1.0(0.0-2.0)$ & $1.0(0.0-2.0)$ & $0.43^{\mathrm{b}}$ \\
\hline Time until detection of sentinel lymph node (minutes) & $14.0(4.0-45.0)$ & $11.0(1.0-31.3)$ & $0.34^{\mathrm{b}}$ \\
\hline
\end{tabular}

${ }^{a} \mathrm{n}(\%) ;$ Chi-square test for trend (Mann-Whitney $\mathrm{U}$ test).

${ }^{b}$ Median (interquartile range); Mann-Whitney $\mathrm{U}$ test. 
There have been reports of a few cases of skin necrosis and fat necrosis following injection of different dyes; however, no complication of this type was found in the present study. ${ }^{27,28}$

In our study, the sentinel lymph node detection rate was $68.1 \%$ in the patent blue group and $60.6 \%$ in the methylene blue group, with no statistically significant difference between the two groups. This detection rate may appear low, but this can be explained by the large number of locally advanced tumors, of cases in which axillary involvement was present and of cases in which neoadjuvant chemotherapy had been performed. Furthermore, physicians undergoing training are given the opportunity to start learning a new specialty in this university teaching hospital. Studies with patent blue alone have shown a detection rate of 60 to $75 \%$ at the beginning of the learning curve. ${ }^{19,29}$

For various reasons, we decided that all patients with invasive carcinomas should be included in the study, even cases lacking conventional indication for sentinel lymph node. This would allow a greater number of cases to be included, providing the team with a better training opportunity and conferring greater statistical power to the analysis. Since the patients were allocated randomly into the groups, there does not appear to be any type of selection bias in comparing the efficacy of each method. Once the sentinel lymph node was identified, the accuracy of the different dyes appears to be similar to rates published in the literature. ${ }^{5,30}$ The degree of technical difficulty appears to be the same in the two groups.

Since the physical examination and imaging tests performed may raise false suspicions, a biopsy of the sentinel lymph node was performed rather than percutaneous lymph node biopsy, and the suspect lymph node was removed separately if not simultaneously, followed by intra-operative evaluation by cytology or histology. Due to the strict study methodology, a lymph node that was considered suspect from a clinical point of view but that had not been stained was not considered a sentinel lymph node.

Use of sentinel lymph node biopsy in clinical practice, despite still involving considerable morbidity, provides better results for the patients than complete axillary dissection. ${ }^{31}$ In certain cases, such as those with larger tumors, following neoadjuvant chemotherapy, or when there is prior axillary involvement, identification of the sentinel lymph node is more difficult and there is a greater risk of false-negative findings. The American College of Surgeons Oncology Group (ACOSOG)'s Z1071 trial and the Sentinel Neoadjuvant (SENTINA) study both reported errors in identifying the sentinel lymph node that exceeded the limit considered acceptable following chemotherapy. ${ }^{32,33}$ It is not yet known whether slightly more false-negative findings could translate into unfavorable oncological results such as a greater incidence of recurrence of the disease and higher mortality. In those studies, the best and most acceptable results were obtained when two types of markers were used, a dye in association with radioactive technetium, and when more than two lymph nodes were removed.

Despite the financial limitations imposed by the healthcare system and by the teaching hospital, we believe that this study represents an important contribution towards being able to offer an alternative to the use of nuclear medicine even when circumstances are unfavorable such as in this study population.

\section{Conclusion}

Methylene blue can be used as a substitute for patent blue in sentinel lymph node biopsies, with no increase in the complication rate or in the degree of technical difficulty, and with the added advantage of lower cost.

\section{Resumo}

Estudo randomizado prospectivo comparando o azul patente ao azul de metileno para a detecção do linfonodo sentinela em pacientes com câncer de mama

Introdução: $\mathrm{O}$ azul de metileno é mais facilmente encontrado para comercialização e a um preço menor que o azul patente. Parece ainda haver menor risco de anafilaxia.

Objetivo: Comparar a taxa de detecção do linfonodo sentinela com o azul patente e com o azul de metileno.

Método: Foram incluídas, de forma randomizada e prospectiva, 142 pacientes com diagnóstico de carcinoma mamário invasor, que consentiram em participar livremente do estudo. Foram injetados $2 \mathrm{~mL}$ de azul patente (grupo A) em 69 (49,3\%) mulheres e de azul de metileno (grupo B) em 71 (50,70\%), em localização periareolar ou peritumoral, seguido de 5 minutos de massagem. Trinta e cinco $(25,0 \%)$ apresentavam estadiamento clínico 3 ou 4 , e $55(38,7 \%)$ apresentavam a axila clinicamente comprometida. Sessenta e nove (49,3\%) fizeram quimioterapia neoadjuvante. Duas pacientes não tinham anotação do corante utilizado e foram excluídas.

Resultados: Os dois grupos apresentaram características das pacientes e dos tumores semelhantes. Foram detectados linfonodos sentinela em $47(68,1 \%)$ mulheres no grupo A e em $43(60,6 \%)$ no grupo B ( $\mathrm{p}=0,35)$. Havia linfonodos sentinela comprometidos em $22(51,2 \%)$ casos 
no grupo A e em $21(48,8 \%)$ casos no grupo B ( $\mathrm{p}=0,62)$. O linfonodo sentinela foi o único gânglio comprometido em $12(54,5 \%)$ casos no grupo A e em seis $(33,3 \%)$ casos no grupo $B(p=0,18)$. O tempo e o grau de dificuldade para identificação do linfonodo sentinela foram semelhantes nos dois grupos. Não houve relato de complicações ou de alergia em nenhum dos grupos.

Conclusão: A utilização do azul de metileno para a identificação do linfonodo sentinela em pacientes com câncer de mama apresenta resultados semelhantes aos do azul patente.

Palavras-chave: câncer de mama, linfonodo sentinela, azul patente, azul de metileno, ensaio clínico randomizado.

\section{RefERENCES}

1. Mansel RE, Fallowfield L, Kissin M, Goyal A, Newcombe RG, Dixon JM, et al. Randomized multicenter trial of sentinel node biopsy versus standard axillary treatment in operable breast cancer: the ALMANAC Trial. J Natl Cancer Inst. 2006; 98(9):599-609.

2. Chua B, Ung O, Boyages J. Treatment of the axilla in early breast cancer: past, present and future. ANZ J Surg. 2001; 71(12):729-36.

3. Veronesi U, Marubini E, Del Vecchio M, Manzari A, Andreola S, Greco M, et al. Local recurrences and distant metastases after conservative breast cancer treatments: partly independent events. J Natl Cancer Inst. 1995; 87(1):19-27.

4. Veronesi U, Paganelli G, Viale G, Luini A, Zurrida S, Galimberti V, et al. A randomized comparison of sentinel-node biopsy with routine axillary dissection in breast cancer. N Engl J Med. 2003; 349(6):546-53.

5. Veronesi U, Viale G, Paganelli G, Zurrida S, Luini A, Galimberti V, et al Sentinel lymph node biopsy in breast cancer: ten-year results of a randomized controlled study. Ann Surg. 2010; 251(4):595-600.

6. Rubio I, Pedreira F, Roca I, Cabaleiro A, Mendoza C, Córdoba O, et al Removal of all radioactive sentinel nodes in breast cancer improves the detection of positive sentinel nodes. Clin Transl Oncol. 2008; 10(6):347-50

7. Galimberti V, Cole BF, Zurrida S, Viale G, Luini A, Veronesi P, et al.; International Breast Cancer Study Group Trial 23-01 investigators. Axillary dissection versus no axillary dissection in patients with sentinel-node micrometastases (IBCSG 23-01): a phase 3 randomised controlled trial. Lancet Oncol. 2013; 14(4):297-305.

8. Giuliano AE, Hunt KK, Ballman KV, Beitsch PD, Whitworth PW, Blumencranz PW, et al. Axillary dissection vs no axillary dissection in women with invasive breast cancer and sentinel node metastasis: a randomized clinical trial. JAMA 2011; 305(6):569-75.

9. Straver ME, Meijnen P, van Tienhoven G, van de Velde CJ, Mansel RE, Bogaerts $\mathrm{J}$, et al. Sentinel node identification rate and nodal involvement in the EORTC 10981-22023 AMAROS trial. Ann Surg Oncol. 2010; 17(7):1854-61.

10. Donker M, van Tienhoven G, Straver ME, Meijnen P, van de Velde CJ, Mansel RE, et al. Radiotherapy or surgery of the axilla after a positive sentinel node in breast cancer (EORTC 10981-22023 AMAROS): a randomised, multicentre, open-label, phase 3 non-inferiority trial. Lancet Oncol. 2014; 15(12):1303-10

11. Giuliano AE, Jones RC, Brennan M, Statman R. Sentinel lymphadenectomy in breast cancer. J Clin Oncol. 1997; 15(6):2345-50.

12. East JM, Valentine CS, Kanchev E, Blake GO. Sentinel lymph node biopsy for breast cancer using methylene blue dye manifests a short learning curve among experienced surgeons: a prospective tabular cumulative sum (CUSUM) analysis. BMC Surg. 2009; 9:2.

13. Varghese P, Abdel-Rahman AT, Akberali S, Mostafa A, Gattuso JM, Carpente R. Methylene blue dye: a safe and effective alternative for sentinel lymph node localization. Breast J. 2008; 14(1):61-7.

14. Eldrageely K, Vargas MP, Khalkhali I, Venegas R, Burla M, Gonzalez KD, et al. Sentinel lymph node mapping of breast cancer: a case-control study of methylene blue tracer compared to isosulfan blue. Am Surg. 2004; 70(1):872-5.

15. Blessing WD, Stolier AJ, Teng SC, Bolton JS, Fuhrman GM. A comparison of methylene blue and lymphazurin in breast cancer sentinel node mapping. Am J Surg. 2002; 184(4):341-5.

16. Masannat Y, Shenoy H, Speirs V, Hanby A, Horgan K. Properties and characteristics of the dyes injected to assist axillary sentinel node localization in breast surgery. Eur J Surg Oncol. 2006; 32(4):381-4.

17. Aydogan F, Celik V, Uras C, Salihoglu Z, Topuz U. A comparison of the adverse reactions associated with isosulfan blue versus methylene blue dye in sentinel lymph node biopsy for breast cancer. Am J Surg. 2008; 195(2):277-8.

18. Thevarajah S, Huston TL, Simmons RM. A comparison of the adverse reactions associated with isosulfan blue versus methylene blue dye in sentinel lymph node biopsy for breast cancer. Am J Surg. 2005; 189(2):236-9.

19. Giuliano AE, Kirgan DM, Guenther JM, Morton DL. Lymphatic mapping and sentinel lymphadenectomy for breast cancer. Ann Surg. 1994; 220(3):391-401.

20. Zuo W, Wang Y, Li M. [Clinical significance of sentinel lymph node biopsy for breast cancer]. Zhonghua Zhong Liu Za Zhi. 2001; 23(3):247-50.

21. Galen RS, Gambino SR. Beyond normality: the predictive value and efficiency of medical diagnoses. New York: John Wiley \& Sons; 1975.

22. Giuliano AE, Chung AP. Long-term follow-up confirms the oncologic safety of sentinel node biopsy without axillary dissection in node-negative breast cancer patients. Ann Surg. 2010; 251(4):601-3.

23. Simmons R, Thevarajah S, Brennan MB, Christos P, Osborne M. Methylene blue dye as an alternative to isosulfan blue dye for sentinel lymph node localization. Ann Surg Oncol. 2003; 10(3):242-7.

24. Piñero A, Illana J, García-Palenciano C, Cañizarese F, Canteras M, Cañadillas $\mathrm{V}$, et al. Effect on oximetry of dyes used for sentinel lymph node biopsy. Arch Surg. 2004; 139(11):1204-7.

25. Teknos D, Ramcharan A, Oluwole SF. Pulmonary edema associated with methylene blue dye administration during sentinel lymph node biopsy. J Natl Med Assoc. 2008; 100(12):1483-4.

26. Gropper AB, Calvillo KZ, Dominici L, Troyan S, Rhei E, Economy KE, et al Sentinel lymph node biopsy in pregnant women with breast cancer. Ann Surg Oncol. 2014; 21(8):2506-11.

27. Reyes FJ, Noelck MB, Valentino C, Grasso-LeBeau L, Lang JE. Complications of methylene blue dye in breast surgery: case reports and review of the literature. J Cancer. 2011; 2:20-5.

28. Bircan HY, Ozcelik U, Koc B, Kemik O, Demirag A. Cutaneous necrosis as a result of isosulphane blue injection in mammarian sentinel lymph node mapping: report of two cases. Clin Med Insights Case Rep. 2014; 7:79-81.

29. O'Hea BJ, Hill AD, El-Shirbiny AM, Yeh SD, Rosen PP, Coit DG, et al. Sentinel lymph node biopsy in breast cancer: initial experience at Memorial SloanKettering Cancer Center. J Am Coll Surg. 1998; 186(4):423-7.

30. Chung A, Giuliano A. Axillary staging in the neoadjuvant setting. Ann Surg Oncol. 2010; 17(9):2401-10.

31. Ashikaga T, Krag DN, Land SR, Julian TB, Anderson SJ, Brown AM, et al.; National Surgical Adjuvant Breast, Bowel Project. Morbidity results from the NSABP B-32 trial comparing sentinel lymph node dissection versus axillary dissection. J Surg Oncol. 2010; 102(2):111-8.

32. Boughey JC, Suman VJ, Mittendorf EA, Ahrendt GM, Wilke LG, Taback B, et al.; Alliance for Clinical Trials in Oncology. Sentinel lymph node surgery after neoadjuvant chemotherapy in patients with node-positive breast cancer: the ACOSOG Z1071 (Alliance) clinical trial. JAMA. 2013; 310(14):1455-61.

33. Kuehn T, Bauerfeind I, Fehm T, Fleige B, Hausschild M, Helms G, et al. Sentinel-lymph-node biopsy in patients with breast cancer before and after neoadjuvant chemotherapy (SENTINA): a prospective, multicentre cohort study. Lancet Oncol. 2013; 14(7):609-18. 